\title{
ECOLOGICAL TOURISM IN UZBEKISTAN
}

\author{
Zebo Mussoyevna Anvarova \\ Bukhara State University, Uzbekistan \\ Istat Elmurodovna Mirzoyeva \\ Bukhara State University, Uzbekistan
}

\section{ABSTRACT}

The following article deals with the tourism possibilities of Uzbekistan that is considered as one of the most convenient countries for both travel and pilgrimage. For the further development of tourism in the country, first of all, we need to improve the necessary infrastructure, ecotourism and its future prospects, as well as the unique beautiful nature of ecotourism, its unique landscape, a variety of unique flora and fauna.

KEYWORDS: - Uzbekistan, travel, pilgrimage, tourism, ecotourism, nature, national nature park, local, flora and fauna, nature reserve, mountain ecosystem, agrotourism, spiritual and cultural heritage.

\section{INTRODUCTION}

Tourism is one of the most important sectors of the economy of the XXI century. Much attention is paid to the further development of this sector, making effective use of existing opportunities around the world, because today the period itself requires the development of tourism on a large scale.

Uzbekistan is one of the most convenient countries for both travel and pilgrimage. During the long historical development in the territory of Uzbekistan there are many great people who are known and famous all over the world. Their rich spiritual and cultural heritage is viewed with great interest in the international arena.
For the further development of tourism in Uzbekistan, first of all, it is necessary to improve their necessary infrastructure. Indeed, today tourism is one of the most profitable sectors of the national economy in the world, and in 2018 in the tourism industry will reach 350 million USD, and more than 830 billion USD in revenue. We can admit that these figures have grown even more in recent years as a result of the development of tourism and tourist services. The tourism industry, in addition to attracting large investments and resources, is also a branch of the economy that performs the spiritual and educational functions necessary for the state and society. At the same time, its non-traditional types - ecotourism, agrotourism, archeological, ethnographic, religious tourism, extreme tourism and others began to appear and develop. 
CURRENT RESEARCH JOURNAL OF PHILOLOGICAL SCIENCES 2(11):

48-52, November 2021

DOI: https://doi.org/10.37547/philological-crjps-02-11-12

ISSN 2767-3758

(C)2021 Master Journals

Crossref doi

gil Google

Accepted25 th November, 2021 \& Published 30 ${ }^{\text {th }}$ November, 2021

It is noteworthy that these areas are recognized by experts as fast-growing areas. The World Tourism Organization recognizes the following types of tourism as the most promising. These are: Adventure tourism, sea and water tourism and ecotourism. Ecotourism is one of the youngest and most promising types of tourism, which is characterized by its development and high income. Indeed, the World Tourism Organization (WTO) has identified trends in the development of eco-tourism, which, according to its forecasts, will be one of the main strategic directions of eco-tourism until 2020. This is explained by the growing share of ecotourism in the global tourism industry in recent years.

The flow of world tourism is shifting from developed countries to developing countries. The tourism industry of developing countries is mainly based on eco-tourism. Professor Askar Nigmatov in his article "Ecotourism and its future prospects in Uzbekistan" noted that ecotourism covers 10-20\% of the tourism market, and the growth rate is several times higher than the overall growth rate of the tourism industry.

Uzbekistan is a region with great potential for the development of tourism in the Central Asian region, including eco-tourism. Indeed, after the independence of the Republic of Uzbekistan, the process of integration into the world community is gaining momentum. In the near future, political, diplomatic, trade, economic and cultural ties with foreign countries are developing. Tourism also has a special place in this relationship. In recent years, this issue has risen to the level of public policy.

The Action Strategy for the five priority areas of development of the Republic of Uzbekistan for 2017-2021 also focuses on the rapid development of the tourism industry, increasing its role and share in the economy, diversifying and improving the quality of tourist services, expanding tourism infrastructure.

Uzbekistan's dependence on ecotourism, unique beautiful nature, unique landscape, diverse flora and fauna, rare, world-class archeological finds, paleontological remains, land

It is natural that rare geological sections, hundreds of natural monuments attract the attention of foreigners. Significant work is being carried out in the Ugam-Chatkal State National Nature Park, the Chatkal State Biosphere Reserve, the AydarArnasay lake system and the Chimgan-Charvak resort and recreation zones, which are part of it, in the development of tourism in Uzbekistan.

In January 1995, in cooperation with UNICEF, the project "Environmental and regional assistance to women and children in the Aral Sea region" "ASPERA" was developed, and on July 31, 1995 the Cabinet of Ministers issued a resolution "On measures to implement the ASPERA project". The project was implemented during 1995-1998 at a cost of $\$ 3.12$ million. At the initiative of the ECOSAN Foundation, great attention is paid to the development of ecotourism in the country. The ECOSAN-TOUR International Center was established in accordance with the recommendations of the I International Conference on Ecotourism and the Great Silk Road, organized by the ECOSAN International Foundation and the F. Ebert Foundation (Germany). The Program for the Development of Service Services in Ecological Tourism has been implemented in recent years. In general, today the main goal of the International Public Fund "ECOSAN" is to address the impact of adverse factors on human health reduction, mitigating the social and environmental consequences of the Aral Sea problem. In 2008 alone, the organization sent humanitarian aid worth 
CURRENT RESEARCH JOURNAL OF PHILOLOGICAL SCIENCES 2(11):

48-52, November 2021

DOI: https://doi.org/10.37547/philological-crjps-02-11-12

ISSN 2767-3758

(C)2021 Master Journals

\section{Crossref doi 81 Google}

Accepted25 $5^{\text {th }}$ November, 2021 \& Published $30^{\text {th }}$ November, 2021

1.8 billion soums to 27 regions by 27 humanitarian trains. The protected areas of Uzbekistan include 9 state reserves with an area of 2,164 km2, 2 national parks with an area of $6,061 \mathrm{~km} 2$ and the Republican Center for Rare Animal Breeding ("Jayron" EcoCenter), 9 state reserves with an area of 12,186 $\mathrm{km} 2$. The total area of protected natural areas is $20,520 \mathrm{~km} 2$, or $5.2 \%$ of the territory of Uzbekistan. According to the United Nation World Tourism Organization, ecotourism will remain one of the five main strategic directions of tourism development until 2020. In recent years, the share of ecotourism in the total volume of the global tourism industry has exceeded $10 \%$, and its growth rate is $2-3$ times higher than the corresponding indicators in the entire tourism industry [1].

Ecotourism refers to travel to places that are "untouched" (relatively untouched) by nature in order to explore and enjoy the attractions. The cultural and ethnographic features of these areas are also of interest to tourists. Ecotourism also ensures the active socio-economic participation of the local population and income from this type of activity. Potential of ecotourism in the republic due to the remoteness of Uzbekistan from the oceans and seas and the small size of natural water bodies, the best places for the development of ecotourism are nature reserves and adjacent areas. Today, there are 7 nature reserves in Tashkent, Jizzakh, Surkhandarya, Kashkadarya, Bukhara and Khorezm regions with a total area of more than 188.33 thousand hectares. These reserves are mainly established to protect endangered species and plants.

Determining the pure economic benefits of ecotourism is a difficult task. The experience of different countries shows that $95 \%$ of the income from ecotourism falls on the economy of local regions (provinces and districts). In addition, the daily expenses of ecotourists are 2-3 times higher than those of other types of tourists. For example, in Costa Rica, one of the world's leading ecotourism regions, a tourist spends an average of $\$ 1,000$ at an ecotourism destination, compared to $\$ 400$ for France. Another example, in the Dominican Republic, tourists pay 18 times more for cruise without harming nature than for cruise ships.

Experience of foreign countries in nature conservation and trade development the largest markets for ecotourism are Costa Rica, Ecuador, Nepal, Kenya, Madagascar and the Northern Hemisphere [5]. In fact, the concept of "ecotourism" is based on the fact that the destination of tourists and the protection of these areas by the public and the government. In Nepal, ecotourism is required to promote the use of natural resources, preserve biodiversity, increase forest cover, protect and enhance flora and fauna, and have a positive impact on landscaping and the use of alternative energy sources. Improving and managing the conservation of natural heritage there is also achieved through the participation and support of the local community. In particular, public programs such as community work, nature education, and leadership training are being conducted with the participation of responsible government officials [6].

In order to prevent the possible damage of ecotourism to nature, first of all, the importance of state control and environmental knowledge in society is immeasurable. State control is based on improving the necessary regulatory framework. International standards and the experience of foreign countries should be used in the improvement. In this regard, it is important that the Republic of Uzbekistan has signed several international conventions and agreements on nature protection. However, our country has not yet joined international agreements on eco-tourism. As examples, we can include the United Nations World 
CURRENT RESEARCH JOURNAL OF PHILOLOGICAL SCIENCES 2(11):

48-52, November 2021

DOI: https://doi.org/10.37547/philological-crjps-02-11-12

ISSN 2767-3758

(C)2021 Master Journals

Crossref do

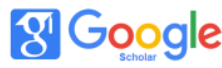

Accepted25 $5^{\text {th }}$ November, 2021 \& Published 30th November, 2021

Tourism Organization's Convention on the Ethics of Tourism and the Quebec Declaration on Ecotourism, which define the role of government, non-governmental organizations and tourists in preventing direct tourism and its possible negative consequences. These international agreements reflect the ethical principles of protecting the development of nature and ecotourism from the negative effects of tourism, the protection of natural and cultural heritage from the negative effects of innovative programs, the role of public and private sectors in determining the development of ecotourism, as well as other important issues. Therefore, it is recommended to apply the principles of the Quebec Declaration on Ecotourism in defining the necessary legal and organizational objectives for the development of ecological and agro-tourism in Uzbekistan. [7]

In this regard, it is worth mentioning one or two foreign experiences on this issue. The role of the state in the development of ecotourism in Singapore is great. In addition to the protection of natural heritage, the state creates various funds for the development of ecotourism, and adopts legislation. It also cooperates with private sector institutions to develop ecotourism. Private institutions such as the Bank of Hong Kong and the Shanghai Bank are sponsoring the Nature Conservation Program in the country. However, environmental problems have been reported in some parts of Singapore. [8]

It is expedient to introduce the practice of developing joint programs in public-private partnership in Uzbekistan. The potential of tourism in the country, especially in the field of ecotourism, does not meet modern requirements. An important factor in creating the necessary conditions for the development of the industry is not only to attract investment, but also to strengthen state control over their rational, environmentally friendly use.

A positive example of the development of ecotourism is the draft resolution of the Cabinet of Ministers "On regulation of the use of certain natural areas and facilities of the Ugam-Chatkal State National Park" developed by the State Committee for Ecology and Environmental Protection [9]. According to the document, a hydrological natural monument will be established in Lake Urungoch and its adjacent area. It is planned to develop ecotourism in the lake area. The main tasks include the preservation and protection of natural lakes and adjacent areas, the restoration of flora and fauna of mountain ecosystems, the organization of ecotourism, the development of scientific and environmental education. Any activity that adversely affects the lake in the monument area is prohibited. It is also planned to install an environmental control post there. Together with the State Committee for Tourism Development, tourist destinations will be identified. In addition, the area will have special corridors for tourists, benches, litter bins, information and prohibition signs, as well as the organization of biotoilets.

Another important aspect of the issue is to increase the environmental awareness of tour operators, government officials and the population operating in the country. The State Committee for Tourism Development and the State Committee for Ecology and Nature Protection can be recommended to develop a "road map" for the development of ecotourism in Uzbekistan. Ecotours should also be developed in cooperation with the State Committee for Ecology and Nature Protection. In order to achieve all United Nation sustainable development goals (especially in the field of environmental and economic sustainability), it is important to develop ecotourism in the Republic of Uzbekistan as an alternative type of tourism. In its development, it is not the conflict of interests of ecology and tourism, but rather cooperation that is important. 
CURRENT RESEARCH JOURNAL OF PHILOLOGICAL SCIENCES 2(11):

48-52, November 2021

DOI: https://doi.org/10.37547/philological-crjps-02-11-12

ISSN 2767-3758

(C)2021 Master Journals

\section{Crossief do) 7 ' Google}

Accepted25 $5^{\text {th }}$ November, 2021 \& Published 30 ${ }^{\text {th }}$ November, 2021

1. Ecotourism in Uzbekistan: prospects and opportunities. July 18, 2018. Available at: https://uzbekistan.lv/en/ecotourism-inuzbekistan-prospects-and-opportunities / (last seen 11.09.2018)

2. Article 5. Adopted by the Legislative Chamber on April 16, 2019. Approved by the Senate on June 21, 2019. National database of legislation, 07/19/2019 № 03/19/549/3446.

http://lex.uz/ru/docs/4428101

3. PKM №978 от 03.12.2018

4. https://www.gazeta.uz/ru/2019/08/15/re serve/

5. http://hozir.org/ozbekiston-respublikasioliy-va-orta-maxsus-talim-vazirligi-buv2.html?page=7; https://www.tourismreview.ru/costa-rica-top-ecoturizm-celnews5183

6. Anup K.C. Ecotourism and Its Role in Sustainable Development of Nepal http://dx.doi.org/10.5772/62308

7. http://hozir.org/ozbekiston-respublikasioliy-va-orta-maxsus-talim-vazirligi-buv2.html?page =7;

8. https://www.bbc.com/news/world-asia44856567

9. https://regulation.gov.uz/uz/document/57 69

10. The factors that influence begetting desertification process. Anvarova Zebo Mussoyevna, Shodiyeva Nigora. South Asian journal of marketing and management research Vol. 10, Issue 11, November 2020

11. Some theoretical issues of social geographical research, Anvarova Zebo Mussoyevna, Shodiyeva Nigora. ASIA LIFE SCIENCES 1(1):1-10,2020

12. Morphological Types of Central Asian Deserts And Their

13. Geographical Aspects. Mirzoyeva Istat Elmurodovna., To'xtayeva Go'zal Fazliddin qizi. The american journal of applied scinces, №3, 2021. 